must be sensitive to new developments, particularly in education. Flexibility is also called for in the techniques of programme planning. As regards technical development, very high frequency, 'VHF', is undoubtedly the radio system of the future. The possibility of stereophonic broadeasting on some regular scheduled basis is just beginning to show above the horizon. Even to-day, some 6 million people who have no television depend entirely on sound for their broadcasting service, and the needs of this audience are as diverse as ever. Extensions which the British Broadcasting Corporation has in mind at present concern particularly the Light Programme and the Third Network. The Corporation also wishes to introduce a completely new service in a system of local broadcasting, but on this the Government has reserved its position. The Corporation has great faith in the potential of this new dimension of sound broadcasting. Administratively, the local stations would be part of its regional system.

\section{Library Service in the Manchester Region}

THE 111th annual report of the Libraries Committee of the City of Manchester covers the year ending March 31, 1963 , in which issues from the lending libraries increased by 45,000 , and from the reference libraries by some 120,000 (Pp. 36. Manchester: The Public Libraries, 1964). The Committee's plans for reorganizing the service have continued, but have fallen far behind the programme approved in January 1960. A feature of the year was the large number of visitors from educational establishments of all kinds and also from overseas. In the technical library, the number of readers increased to a new record of 830,000 and additions during the year brought the total stock to 101,000 volumes. The technical lending library's book stock now exceeds 19,000 volumes and more than 16,000 volumes were issued from the collection during the year, but the phenomenal issue from the patents library of the previous year decreased by some 5 per cent. The use made of the information services to firms and institutions throughout Britain continued to expand. The collection of technical translating dictionaries in all the major languages now exceeds 500 volumes.

A guide to some of the resources available in the technical library at the Central Library, Manchester, in addition to books has been published by the Libraries Committeo (What's Available in the Technical Library: a Guide to Some of the Resources in Addition to Books. By F. R. Taylor. Second Edition. Pp. 29. Manchester: Libraries Committee. Available from the technical librarian, Central Library, 1964. 2s. 6d.). In it Mr. Taylor describes the whole range of resources in detail, and particularly the periodicals, periodical indexes and abstracts, periodical location guides, standards, atomic energy documents, trade catalogues, literature surveys, technical translating dictionaries, patents and micro-texts. Finally, Mr. Taylor explains the service that is offered to industry and the way in which the library forms an integral part of the national library network.

\section{Termite Studies in Africa}

A COLLOQUIUM on African termites was held at the Lovanium University, Leopoldville, during May 11-16 and was organized jointly by the University and Unesco. M. Michel Colin, Minister for Education, République du Congo, presided at the opening session. The attendance of delegates from abroad was facilitated by Unesco in arranging a meeting of the Termite Sub-committee of the Humid Tropics Research Programme in Leopoldville during the course of the colloquium. In the ten years which have passed since the founding of Lovanium, Prof. A. Bouillon has developed a large and active Department of Zoology, in which special attention has been directed to the investigation of the Isoptera, a group of insects well represented in the grounds of the Univer- sity. In his opening address, Prof. Bouillon stressed the importance of termite investigations from both the scientific and the economic points of view, not only to the Congo but also to the Tropics as a wholo. In the 22 papers presented by workers at Lovanium a wide range of interests was exhibited, covering taxonomy, morphology, social behaviour and ecology, with special reference to the large mound-building Macrotermes natalensis, a new spocies of Cubitermes making small mounds in grassland, and three species of the genus Apicotermes, the elegant subterranean nests of which are one of the marvels of insect architecture. Co-operation with workers in other departments of the University has resulted in interosting developments in techniques and apparatus for investigating termites; for example, the use of microanemometers to measure air-flow in mounds, the estimation of pterines and their possible role as regulators in the sexual cycle, and the application of pedological techniques to investigations of mounds. A number of papers were con. tributed by the visiting entomologists. The proceedings of the colloquium are in course of publication by the University in its series Studia Universitas Lovanium.

\section{Stonehenge}

STONEHENGe has always fascinated everyone who has visited the monument. Who mado it and when and why was it orected? The first two queries have now been answered by the archæologist with reasonable certainty, though to what extent, if any, Mycenæan architects helped in the erection remains doubtful. But the reasons why the building was put up are less certain; clearly it was not for fun. Years ago, Sir Norman Lockyor pointed out that the orientation of some of the stones made it clear that a line on the rising of the Sun at midsummer could be obtained, and that, therefore, the 'temple' was of the nature of a calendar. Such a purpose would, of course, be vital for an agricultural people, who would want to know when to sow their crops, etc. Articles on the subject by Prof. G. Hawkins have recently appeared in Nature $(200,306 ; 1963$; and 202,$1258 ; 1964)$. At the same time, and seemingly independently, Mr. C. A. Newham has published a pamphlet on the samo problem (The Enigma of Stonehenge and its Astronomical and Geometrical Significance. Pp. 42. Tadcaster: C. A. Newham, 5 Sedge Rise, 1964). Both agree that the 'priests' at Stonehengo were interested in the Moon as well as in the Sun at midsummer, but Mr. Newham goes further and brings the Pleiades into the picture. Many authorities, when writing about Stonehenge, refer to Diodorus, an author who was writing about 50 B.C. In one passage he is thought to be describing the monument, and he mentions the Metonic (19 year) cycle which does, of course, involve the Moon. Unfortunately, the exact original position of every stone cannot be determined with complete accuracy, and, as $\mathrm{Mr}$. Newham points out, much of the work can be likened to trying to aim a gun when the back sights are defective. It is interesting to find two investigators working independently on this problem, and much information can be gainod from both.

\section{Applied Science and Technology in Japan}

OF the Memoirs published periodically by the Faculty of Industrial Arts, Kyoto Technical University, Matsugasaki, Sakyoku, Kyoto, Japan, Science and Technology (12, December 1963) gives an impression of the versatility of the research work carried on in this important institution. This issue, entirely in English, contains six papers: measurement of fibre fineness by horizontal air-flow, by M. Uno, A. Shiomi and Y. Yanagawa; approximation theory of general thin elastic shells, by O. Matsuoka; autoxidation of alcohols and their reactivities, by S. Kato and F. Mashio; mineralogical study on the Brazilian aluminium phosphate oros, by T. Arimori and N. Yoshida; on the flow of flaming gases in the end-fired glass melting tank furnace, by K. Terada and M. Wakamatsu; and on 